\title{
Resistance Against Melon Chlorotic Mosaic Virus and Tomato Leaf Curl New Delhi Virus in Melon
}

\author{
Gustavo Romay, ${ }^{1,2}$ Michel Pitrat, ${ }^{3}$ Herve Lecoq, ${ }^{1}$ Catherine Wipf-Scheibel, ${ }^{1}$ Pauline Millot, ${ }^{1}$ Gregory Girardot, ${ }^{1}$ and Cecile Desbiez, ${ }^{1, \dagger}$ \\ ${ }^{1}$ Institut National de la Recherche Agronomique (INRA), Unité de Pathologie Végétale, Domaine St. Maurice, Montfavet cedex, \\ France \\ ${ }^{2}$ Université Catholique de Louvain, Earth and Life Institute, Phytopathology, Louvain-la-Neuve, Belgium \\ ${ }^{3}$ INRA, Unité de Génétique et Amélioration des Fruits et Légumes, Domaine St. Maurice, Montfavet cedex, France
}

\begin{abstract}
Thirty-one melon accessions were screened for resistance to the begomoviruses Melon chlorotic mosaic virus (MeCMV) and Tomato leaf curl New Delhi virus (ToLCNDV). Five accessions presented nearly complete resistance to both viruses. Accession IC-274014, showing the highest level of resistance to both viruses, was crossed with the susceptible cultivar Védrantais. The $\mathrm{F}_{1}, \mathrm{~F}_{2}, \mathrm{~F}_{3} / \mathrm{F}_{4}$, and both backcross progenies were mechanically inoculated with MeCMV. Plants without symptoms or virus detection by enzyme-linked immunosorbent assay and/or PCR were considered as resistant. The segregations were compatible with two re-

simultaneously required. Some $\mathrm{F}_{3}$ and $\mathrm{F}_{4}$ families selected for resistance to MeCMV also were resistant to ToLCNDV, suggesting that common or tightly linked genes were involved in resistance to both viruses. We propose the names begomovirus resistance- 1 and Begomovirus resistance- 2 for these genes (symbols bgm-1 and Bgm-2). Resistance to MeCMV in IC-274014 was controlled by bgm-1, Bgm-2, and the recessive gene melon chlorotic mosaic virus resistance (mecmv); resistance to ToLCNDV was controlled by bgm-1, Bgm-2, and the dominant gene Tomato leaf curl New Delhi virus resistance (Tolcndv).
\end{abstract} cessive and one dominant independent genes simultaneously required for resistance. Inheritance of resistance to ToLCNDV in the $\mathrm{F}_{2}$ was best explained by one recessive gene and two independent dominant genes
Keywords: begomovirus, Cucumis melo, genetic control, inheritance, MeCMV, ToLCNDV
Melon (Cucumis melo L.) is one of the major crop species in the family Cucurbitaceae. Global production of melon is approximately 30,000,000 tons per year (www.fao.org/faostat). Cucurbit diseases caused by begomoviruses (genus Begomovirus, family Geminiviridae) are a new threat to cucurbit production worldwide. At least six and eight Begomovirus species from the New World (NW) and Old World (OW), respectively, have been described infecting cucurbits in the past 30 years (Brown et al. 2015). Some of them have a narrow geographic distribution despite a high local prevalence and agronomic impact, like the NW Begomovirus Melon chlorotic mosaic virus (MeCMV) observed only in Venezuela so far (Romay et al. 2010). Others have a larger geographic range: the NW Begomovirus Squash leaf curl virus (SLCV) and the OW Begomovirus Watermelon chlorotic stunt virus (WmCSV) were introduced into the Eastern Mediterranean Basin in the early 2000s (Lapidot et al. 2014). The OW Tomato leaf curl New Delhi virus (ToLCNDV), first described in India, was more recently reported in Europe and in the north of Africa (Fortes et al. 2016), where it has rapidly become a major agronomic problem (Moriones et al. 2017). Control of begomoviruses relies on the limitation of their vector Bemisia tabaci, mostly by intensive insecticide treatments, and on genetic resistance when available. Considering the frequent emergence of highly damaging

${ }^{\dagger}$ Corresponding author: C. Desbiez; cecile.desbiez@inra.fr

Funding: This work was funded in part through the EMERAMB project in the ARIMNet2 2015 Call. ARIMNet2 (2014-2017) is an ERA-NET coordinated by INRA (France). It has received funding from the European Union's Seventh Framework Programme for research, technological development and demonstration under grant agreement no. 618127.

*The $\boldsymbol{e}$-Xtra logo stands for "electronic extra" and indicates that four supplementary tables are published online.

The author(s) declare no conflict of interest.

Accepted for publication 6 May 2019.

(C) 2019 The American Phytopathological Society begomoviruses, breeding for resistance is a key factor for a durable control, particularly if broad-spectrum resistances effective against several viruses at once can be found.

In melon, resistances to different viruses and pathogens are often found in the same genotype (Table 1) even when the resistance factors are distinct (Lecoq et al. 1998). Resistances to WmCSV (Yousif et al. 2007), Cucurbit leaf crumple virus (CuLCrV) (Hagen et al. 2008b; McCreight et al. 2008), and more recently ToLCNDV (López et al. 2015), have been described; however, there is no evidence for general resistance factors against several of these viruses

In this work, we looked for resistance against the genetically distant MeCMV (NW) and ToLCNDV (OW) and checked whether common genetic factors could target these two viruses. In a first step, we screened 31 melon accessions, previously described as resistant to at least one virus or representative of the phenotypic melon diversity. We also tested the inheritance of resistance to MeCMV in the most resistant accession IC-274014 and its relationship with resistance to ToLCNDV, in order to find efficient and generic resistance factors that could be used in breeding programs.

\section{Materials and Methods}

Virus strains and infectious clones. MeCMV was collected from watermelon [Citrullus lanatus (Thumb.) Matsum. and Nakai] in Zulia, Venezuela. A multimeric infectious clone of this virus was obtained in a previous work (Romay et al. 2015). A ToLCNDV (ES13-35) isolate was obtained from a leaf sample of zucchini squash (Cucurbita pepo L.) from Murcia, Spain. Total DNA was extracted from the infected plant as described by Gilbertson et al. (1991), and ToLCNDV detection was confirmed by sequencing of a PCR fragment amplified using universal primers for begomoviruses (Wyatt and Brown 1996). The full-length genome sequence of this isolate was obtained for further constructions of a multimeric infectious clone.

The complete genome of ES13-35 isolate was amplified by rolling circle amplification (RCA) according to the manufacturer's recommendations (Romay et al. 2015). The DNA-A fragment generated by RCA was digested with XbaI and XhoI ( 1 kb) and inserted into pBluescript II SK (+) (Stratagene, La Jolla, CA). Then, a complete DNA-A was linearized with $\mathrm{BamHI}$ and inserted into the plasmid 
containing the $\mathrm{XbaI}-\mathrm{XhoI}$ fragment. To generate a multimeric clone of DNA-B, a 1.6-kb fragment was obtained by digestion of RCA product with PstI and insertion into pBlueScript. Then, a complete DNA-B fragment after $M l u I$ digestion of the RCA product was ligated to the previously clone containing the $1.6-\mathrm{kb}$ fragment and linearized with $M l u \mathrm{I}$. For cloning of both DNA components, Escherichia coli strain DH5 alpha was used as host of plasmid constructs.

The infectivity of the clones was confirmed by bombardment of melon seedlings according to Romay et al. (2015).

Viral inoculation assays. Melon seedlings of the susceptible cultivar Védrantais, inoculated with infectious clones of ToLCNDV and MeCMV, were used as virus sources for mechanical inoculations. One gram of young infected leaf tissue was ground in $5 \mathrm{ml}$ of an ice-cold solution of $0.03 \mathrm{M} \mathrm{Na}_{2} \mathrm{HPO}_{4}+0.2 \%$ diethyldithiocarbamate. Activated charcoal and carborundum were added to the sap extract (Romay et al. 2015). Two successive inoculations were performed for each melon seedling: a first one on the cotyledons at 6 days post sowing, followed by a second inoculation onto the first true leaf 6 days later, as described by Romay et al. (2015). Symptoms were checked visually at weekly intervals. At 30 days postinoculation (dpi), young leaves were collected from all plants for accessions that did not show any symptoms, and one plant per accession in the accessions that displayed symptoms, for serological or molecular virus detection. All inoculated plants were kept in biosafety level 3 (S3) greenhouse.

Virus detection [enzyme-linked immunosorbent assay (ELISA), PCR]. Begomovirus detection was performed by PCR as described by Romay et al. (2015), with primers 64ACR5 and 64debAC3 (Romay et al. 2014) for MeCMV and primers TLCNDV-CP-5' (5'ATGKYGAAGCGACCAGCAGA-3') and TLCNDV-CP-3' $3^{\prime}$ (5'CCGAATCATARAARTAGATCCG-3') for ToLCNDV.

For the studies on $\mathrm{F}_{2}$ and backcrosses (BCs) with MeCMV, all plants were tested in double-antibody sandwich (DAS)-ELISA with an antiserum against SLCV (Cohen et al. 1983; courtesy of J.E. Duffus) that presents a strong cross-reactivity with MeCMV.

For the studies on $\mathrm{F}_{3}$ and $\mathrm{F}_{4}$ progenies, asymptomatic plants were tested by DAS-ELISA with a ToLCNDV antiserum (Agdia EMEA, Grigny, France) also presenting a strong cross-reactivity with MeCMV (data not shown).

Plant material. Screening for resistance. Thirty-one melon accessions were selected from a germplasm collection at Institut National de la Recherche Agronomique (INRA, Avignon, France) for the resistance screening experiments. Most of the selected accessions had

Table 1. Behavior of 31 melon accessions after artificial inoculation with two begomoviruses: Melon chlorotic mottle virus and Tomato leaf curl New Delhi virus

\begin{tabular}{|c|c|c|c|}
\hline Melon accession & Known resistance against cucurbit viruses ${ }^{a}$ & MeCMV b $^{b}$ & ToLCNDV $^{b}$ \\
\hline Védrantais & & $\mathrm{S}$ & $\mathrm{S}$ \\
\hline Ouzbèque 1 & & $\mathrm{~S}$ & $\mathrm{~S}$ \\
\hline Ouzbèque 2 & & $\mathrm{~S}$ & $S$ \\
\hline Isabelle & & $\mathrm{S}$ & $S$ \\
\hline Anso 77 & & $\mathrm{~S}$ & S \\
\hline AR Hale's Best Jumbo & & $\mathrm{S}$ & $\mathrm{S}$ \\
\hline Canton & & $\mathrm{S}$ & $\mathrm{S}$ \\
\hline HSD 93-20-A & CVYV (systemic necrosis) ${ }^{\mathrm{c}}$ & $\mathrm{S}$ & S \\
\hline PMR-5 & MNSVd & $\mathrm{S}$ & S \\
\hline WMR29 & $\mathrm{PRSV}^{\mathrm{e}}, \mathrm{MWMV}^{\mathrm{e}}, \mathrm{MRMV}^{\mathrm{e}}$ & $\mathrm{S}$ & S \\
\hline PI 161375 & $\mathrm{CMV}^{\mathrm{e}}, \mathrm{MNSV}^{\mathrm{e}}$ & $\mathrm{S}$ & $\mathrm{S}$ \\
\hline PI 164323 & $\mathrm{CVYV}^{\mathrm{c}}$ & $\mathrm{S}$ & S \\
\hline PI 179905 & $\mathrm{ZYMV}^{\mathrm{c}}$ & $\mathrm{S}$ & $S$ \\
\hline PI 234607 & $\mathrm{CuLCrV}^{\mathrm{f}}$ & $\mathrm{S}$ & $S$ \\
\hline PI 255478 & CABYVg & $\mathrm{S}$ & $\mathrm{S}$ \\
\hline PI 482420 & $\mathrm{CYSDV}^{\mathrm{e}}, \mathrm{WMV}^{\mathrm{c}}$ & $\mathrm{S}$ & $S$ \\
\hline PI 236355 & $\mathrm{CuLCrV}^{\mathrm{f}}$ & $\mathrm{S}$ & $S$ \\
\hline PI 164723 & $\mathrm{WmCSV}^{\mathrm{h}}$ & $\mathrm{S}$ & IR \\
\hline AM 87 & & $\mathrm{H}(\mathrm{S} / \mathrm{IR} / \mathrm{R})$ & $\mathbf{R}$ \\
\hline HSD 2445-005 & $\mathrm{WmCSV}^{\mathrm{h}}$ & $\mathrm{H}(\mathrm{S} / \mathrm{R})$ & $\mathrm{H}(\mathrm{R} / \mathrm{IR})$ \\
\hline HSD $2458 \mathrm{~B}$ & $\overline{\mathrm{CVYV}^{\mathrm{c}}}$ & $\mathrm{H}(\mathrm{S} / \mathrm{IR} / \mathrm{R})$ & $\mathrm{H}(\mathrm{IR} / \mathrm{R})$ \\
\hline Tibish Kordofan & & $\mathrm{H}(\mathrm{S} / \mathrm{R})$ & $\mathrm{H}(\mathrm{S} / \mathrm{IR} / \mathrm{R})$ \\
\hline MR-1 & $\mathrm{CuLCrV}^{\mathrm{f}}, \mathrm{LIYV}^{\mathrm{e}}$ & $\mathrm{H}(\mathrm{S} / \mathrm{IR} / \mathrm{R})$ & IR \\
\hline PI 179901 & $\mathrm{CuLCrV}^{\mathrm{f}}$ & $\mathrm{H}(\mathrm{S} / \mathrm{IR} / \mathrm{R})$ & $\mathbf{R}$ \\
\hline PI 313970 (90625) & $\overline{\mathrm{CABYV}}^{\mathrm{g}}, \mathrm{CuLCrV}^{\mathrm{f}}, \mathrm{CYSDV}^{\mathrm{c}}, \mathrm{LIYV}^{\mathrm{c}}, \mathrm{WmCSV}^{\mathrm{h}}$ & $\mathrm{H}(\mathrm{S} / \mathrm{R})$ & $\mathrm{H}(\mathrm{S} / \mathrm{IR} / \mathrm{R})$ \\
\hline PI 414723 & $\mathrm{CABYV}^{\mathrm{g}}, \mathrm{CuLCrV}^{\mathrm{f}}, \mathrm{PRSV}^{\mathrm{e}}, \mathrm{ToLCNDV}^{\mathrm{i}}, \mathrm{WmCSV}^{\mathrm{h}}, \mathrm{WMV}^{\mathrm{e}}, \mathrm{ZYMV}^{\mathrm{e}}$ & $\mathrm{H}(\mathrm{S} / \mathrm{IR} / \mathrm{R})$ & $\mathrm{H}(\mathrm{IR} / \mathrm{R})$ \\
\hline IC-274014 & $\mathrm{CABYV}^{\mathrm{c}}, \mathrm{ZYMV}^{\mathrm{c}}$ & $\mathbf{R}$ & $\mathbf{R}$ \\
\hline PI 124112 & $\mathrm{CABYV}^{\mathrm{g}}, \mathrm{CuLCrV}^{\mathrm{f}}, \mathrm{PRSV}^{\mathrm{e}}, \mathrm{ToLCNDV}^{\mathrm{i}}, \mathrm{WmCSV}^{\mathrm{h}}$ & $\mathbf{R}$ & $\mathbf{R}$ \\
\hline PI 282448 & CABYVg, $\mathrm{WmCSV}^{\mathrm{h}}$ & $\mathbf{R}$ & $\mathbf{R}$ \\
\hline WM7 & ToLCNDV & $\mathbf{R}$ & $\mathbf{R}$ \\
\hline WM9 & ToLCNDV $^{i}$ & $\mathbf{R}$ & $\mathbf{R}$ \\
\hline
\end{tabular}

${ }^{a} \mathrm{CABYV}=$ Cucurbit aphid-borne yellow virus (polerovirus), $\mathrm{CMV}=$ Cucumber mosaic virus (cucumovirus), CuLCrV = Cucurbit leaf crumple virus (begomovirus), $\mathrm{CYSDV}=$ Cucurbit yellow stunting disorder virus (crinivirus); $\mathrm{CVYV}=$ Cucumber vein yellowing virus (ipomovirus), LIYV $=$ Lettuce infectious yellow virus (crinivirus), MNSV = Melon necrotic spot virus (carmovirus), MRMV = Melon rugose mosaic virus (tymovirus), MWMV = Moroccan watermelon mosaic virus (potyvirus), $\mathrm{PRSV}=$ Papaya ringspot virus (potyvirus), $\mathrm{WMV}=$ Watermelon mosaic virus (potyvirus), WmCSV = Watermelon chlorotic stunt virus (begomovirus), ZYMV = Zucchini yellow mosaic virus (potyvirus). Begomoviruses (CuLCrV, MeCMV, ToLCNDV, WmCSV) are underlined.

${ }^{\mathrm{b}} \mathrm{MeCMV}=$ Melon chlorotic mottle virus; ToLCNDV = Tomato leaf curl New Delhi virus; $\mathrm{R}=$ resistant; $\mathrm{S}=$ susceptible; $\mathrm{IR}=$ intermediate resistance; $\mathrm{H}=$ heterogeneous. The highest levels of resistance observed in this study are indicated in bold.

c Pitrat 2016a.

d Mallor et al. 2003

${ }^{\text {e }}$ Lecoq et al. 1998.

${ }^{\mathrm{f}}$ McCreight et al. 2008.

${ }^{g}$ Dogimont et al. 1996.

${ }^{\text {h }}$ Yousif et al. 2007.

i López et al. 2015. 
been previously reported to be resistant or tolerant to at least one plant pathogen; others were representative of the phenotypic melon diversity (Pitrat 2016a, b) (Table 1). Ten plants of each melon accession were used for each virus in two independent tests.

Inheritance studies. The melon accession IC-274014 belongs to the group momordica (Pitrat 2016b) and was supplied by N.P.S. Dhillon (Dhillon et al. 2007). It was crossed with the cultivar Védrantais belonging to the group cantalupensis subgroup charentais (obt. Vilmorin). The $\mathrm{F}_{1}$ hybrid was selfed to obtain the $\mathrm{F}_{2}$ progeny and backcrossed to IC-274014 or Védrantais to obtain respectively the $\mathrm{BC}_{\mathrm{R}}$ and $\mathrm{BC}_{\mathrm{S}}$ progenies. The parents, $\mathrm{F}_{1}, \mathrm{~F}_{2}$, and both $\mathrm{BCs}$ were mechanically inoculated with MeCMV in two independent tests. A third test was conducted for MeCMV with only the susceptible parent Védrantais and the $\mathrm{F}_{2}$ progeny. Ten resistant $\mathrm{F}_{2}$ plants (no symptom, no virus detected by ELISA and PCR after inoculation with $\mathrm{MeCMV}$ ) were selfed to produce $10 \mathrm{~F}_{3}$ progenies. As only a few seeds with low germination ability have been obtained in the $\mathrm{F}_{3}$ progeny, two to four plants, without selection for virus resistance or susceptibility, from each $\mathrm{F}_{3}$ progeny were selfed to obtain $\mathrm{F}_{4}$ families.

The $\mathrm{F}_{1}$ and $\mathrm{F}_{2}$ progenies (IC-274014 $\times$ Védrantais) were mechanically inoculated with ToLCNDV. Besides, plantlets of the $\mathrm{F}_{3}$ progenies deriving from the $\mathrm{F}_{2}$ selected for resistance to MeCMV, and of the corresponding $\mathrm{F}_{4}$, were mechanically inoculated with ToLCNDV to determine if the same genes were involved in resistance to both viruses.

Correlation with resistance to other cucurbit-infecting viruses. Resistance of the $F_{4}$ (IC-274014 $\times$ Védrantais) progenies to Zucchini yellow mosaic virus $(Z Y M V)$. Ten plantlets of Védrantais, IC 274014 and of the $\mathrm{F}_{4}$ progenies at the cotyledonary stage were mechanically inoculated with strain E15 of ZYMV (Lecoq and Pitrat 1984). Symptoms were recorded weekly and an ELISA test was performed 4 weeks after inoculation on the asymptomatic plants.

Behavior of melon accession and of six of the $F_{4}(I C-274014 \times$ Védrantais) progenies toward Cucurbit aphid-borne yellows virus $(C A B Y V)$. A field assay was performed to test for the resistance to CABYV. An experimental plot was planted in July 2018 with 20 plants of Védrantais and 10 plants each of 11 accessions (HSD 2445-005, IC-274014, PI 164323, PI 164723, PI 179901, PI 234607, PI 236355, PI 414723, PI 482420, WM7, and WM9), the $\mathrm{F}_{1}$ hybrid (IC-274014 $\times$ Védrantais), and six of the $\mathrm{F}_{4}$ (IC-274014 $\times$ Védrantais) progenies. The plantlets were planted in four rows of 50 plants each, with $1.5 \mathrm{~m}$ between ranks and $0.8 \mathrm{~m}$ between plants in a rank. Two blocks of five plants each were planted for each accession including the resistant control PI 414723, and four blocks for the susceptible control Védrantais. Two months after planting, an ELISA test was performed with antisera against CABYV, ZYMV, Watermelon mosaic virus (WMV), and Cucumber mosaic virus (CMV).

\section{Results}

Infectivity of MeCMV and ToLCNDV clones. The full-length genome of the ToLCNDV isolate ES13-35 (GenBank accession numbers MK279352 and MK279353 for DNA-A and DNA-B, respectively) showed at least $99 \%$ nucleotide identity with isolates previously reported in southern Spain (Juárez et al. 2014; Moriones et al. 2017; Ruiz et al. 2015). After biolistic inoculation of seedlings of the susceptible cultivar Védrantais with multimeric clones of ToLCNDV and MeCMV, viral symptoms could be observed between the first and second week postinoculation: severe mosaics, leaf crumpling, and stunting (more severe for MeCMV than for ToLCNDV) with occasional enations on the lower leaf surface for MeCMV only. The presence of each virus was confirmed by PCR at 30 dpi. Mechanical inoculation of both begomoviruses from these sources yielded $100 \%$ infection in Védrantais in all experiments.

Resistance to MeCMV and ToLCNDV in melon accessions. Among the 31 melon lines tested, 17 were susceptible to both MeCMV and ToLCNDV (Table 1). In the susceptible accessions, as well as in Védrantais, symptoms induced by MeCMV were usually more severe than those of ToLCNDV with severe stunting, leaf crispation, and occasionally leaf enations (data not shown).
Among the 14 remaining accessions, heterogeneous response (susceptibility/intermediate resistance/resistance) or intermediate resistance was observed in eight melon lines for MeCMV and in seven melon lines for ToLCNDV. The symptoms that were predominantly observed in intermediate-resistant melon were systemic chlorotic spots. Interestingly, several accessions exhibited a "recovery" phenotype, with more symptoms in the first leaves at 7 dpi than in young leaves at 30 dpi. This was the case for the melon lines PI 164723, PI 414723, and 90625 for ToLCNDV; AM 87, PI 414723, and PI 179901 when inoculated with MeCMV. PCR analyses confirmed the presence of the viruses in all symptomatic plants, including the "recovered" ones that showed almost no symptoms at their apex, but also in a few asymptomatic ones (data not shown).

Accessions IC-274014, WM7, WM9, PI 124112, and PI 282448 did not show any symptoms after inoculation by ToLCNDV or MeCMV. PCR results indicated the occasional presence of viruses in asymptomatic plants (data not shown). Accessions AM 87 and PI 179901 presented a complete resistance to ToLCNDV but a heterogeneous behavior toward MeCMV, with some plants displaying yellow spots or mosaics (Table 1).

Determinism of IC-274014 resistance to MeCMV. Védrantais exhibited severe mosaic symptoms, stunting, and enations when inoculated with MeCMV, and the virus was clearly detected by ELISA or PCR. IC-274014 exhibited no symptoms and the virus was not detected. The $\mathrm{F}_{1}$ (IC-274014 $\times$ Védrantais) exhibited systemic chlorotic spots and the virus was detected in apical leaves (Fig. 1), indicating a recessive genetic control for virus infection. As expected for a recessive genetic control, the $\mathrm{BC}_{\mathrm{S}}$ was fully susceptible (Table 2). All the $\mathrm{BC}_{\mathrm{S}}$ plants exhibited a range of symptoms: severe mosaic and stunting, mild mosaic or mottle, or systemic chlorotic spots and the virus was detected by ELISA in all the plants. In the $\mathrm{BC}_{\mathrm{R}}$ progeny, some plants had no symptoms, but most exhibited symptoms varying from systemic chlorotic spots to mottle; the virus was not detected by ELISA and/or PCR in 29 of 95 plants (Table 2). This observed segregation fitted a three susceptible:one resistant ratio expected for two independent recessive genes, both required to confer resistance.

In the $\mathrm{F}_{2}$ progeny, all types of symptoms were observed (mosaic, mottle, most with systemic chlorotic spots) and some plants had no visible symptoms. The virus was detected by ELISA and/or PCR in all the plants with symptoms and in a few plants without clear symptoms. The observed segregation ( 409 susceptible vs. 20 resistant plants) was compatible with a 15 susceptible (positive in ELISA or PCR) versus 1 resistant (negative in ELISA or PCR) ratio $\left(\chi^{2}=1.846\right.$; $\mathrm{df}=1$; probability $=17 \%$ ) corresponding to a genetic control by two independent recessive genes required simultaneously for resistance.

After selfing $F_{2}$ resistant plants, two $F_{3}$ families (1A6 and 1A8) appeared resistant to MeCMV (Table 3). The eight other $\mathrm{F}_{3}$ families obtained by selfing of resistant $\mathrm{F}_{2}$ plants were segregating, with some plants showing symptoms of mottling or systemic chlorotic spots and virus systemic spread as detected by ELISA. If only two recessive genes were required and sufficient to confer resistance to MeCMV, all the $F_{3}$ and $F_{4}$ plants issued from resistant $F_{2}$ plants should be resistant. It is the case only for $1 \mathrm{~A} 8$ and the associated $\mathrm{F}_{4}$ progenies. The $\mathrm{F}_{3} 1 \mathrm{~A} 6$ appeared fully resistant, but only six plants were tested and the corresponding $\mathrm{F}_{4}$ were either segregating (1A6A and $1 \mathrm{~A} 6 \mathrm{~B}$ ) or susceptible (1A6C). The $\mathrm{F}_{3} 1 \mathrm{~A} 6$ can therefore be considered as also segregating. The high frequency of segregating $F_{3}$ could be explained by the need of a third dominant gene. This hypothesis of a third dominant gene does not change the expected segregation in the $\mathrm{F}_{1}, \mathrm{BC}_{\mathrm{S}}$, and $\mathrm{BC}_{\mathrm{R}}$ progenies. Indeed, the $\mathrm{F}_{1}$ and $\mathrm{BC}_{\mathrm{S}}$ are all susceptible because the recessive resistance alleles are not present in a homozygous state whatever the state of the dominant allele. For the $\mathrm{BC}_{\mathrm{R}}$, the dominant resistance allele is present in all plants either in a homozygous or a heterozygous state, so the resistance or susceptibility depends only on the state of the two recessive alleles. Under the hypothesis of two recessive and one dominant genes simultaneously required for resistance, the expected segregation in the $F_{2}$ would be 61 susceptible versus 3 resistant. The observed segregation (409 susceptible vs. 20 resistant plants) fits this hypothesis (Table 2). 
In the case of two recessive and one dominant genes simultaneously required for resistance, the $\mathrm{F}_{2}$ resistant plants must be homozygous for the two recessive genes but can be homozygous or heterozygous for the third dominant gene. If the three genes are independent, one of three of the $\mathrm{F}_{2}$ resistant plants should be homozygous for the dominant gene producing homogeneous resistant $\mathrm{F}_{3}$ progenies and two of three of the $\mathrm{F}_{2}$ should be heterozygous, producing segregating $\mathrm{F}_{3}$ progenies. The observed segregation (one homozygous $\mathrm{F}_{3}$ progeny vs. nine segregating ones) fits this hypothesis: $\chi^{2}=$ $2.450(\mathrm{df}=1$; probability $=12 \%)$ even if the power of the statistical analysis is low because of the small number of $\mathrm{F}_{3}$ families available. Excluding the resistant 1A8 family, the observed segregation for the number of susceptible or resistant plants (43 susceptible vs. 93 resistant, Table 3 ) among the nine segregating $\mathrm{F}_{3}$ families fits the hypothesis of one susceptible versus three resistant corresponding to the expected segregation for a single dominant gene $\left(\chi^{2}=3.177 ; \mathrm{df}=1\right.$; probability $=7 \%$ ).

Similarly, in the $\mathrm{F}_{4}$ generation obtained by selfing $\mathrm{F}_{3}$ plants without selection for resistance or susceptibility, it was expected a three susceptible versus five resistant ratio in the number of $F_{4}$ plants. As the number of plants in the $\mathrm{F}_{4}$ families varies from 20 (corresponding to the $F_{3} 1 \mathrm{~A} 4$ or $1 \mathrm{~A} 11$ ) to 80 (corresponding to the $\mathrm{F}_{3}$ 1A5), it had to be adjusted to the same number of $F_{4}$ plants for each $\mathrm{F}_{3}$ progeny to test the 3:5 segregation (Supplementary Table $\mathrm{S} 1$ ). The observed segregation fits this hypothesis $\left(\chi^{2}=0.085\right.$; $\mathrm{df}=1$; probability $=77.1 \%$ ).

In summary, the segregations observed for resistance to MeCMV in all the progenies $\left(\mathrm{F}_{1}, \mathrm{BC}, \mathrm{F}_{2}, \mathrm{~F}_{3}\right.$, and $\left.\mathrm{F}_{4}\right)$ fit the hypothesis of two recessive and one dominant independent genes, which can be provisionally symbolized $a, b$, and $C$.

Resistance to ToLCNDV. After mechanical inoculation with ToLCNDV, Védrantais exhibited severe mosaic symptoms and the virus was detected in ELISA, whereas IC-274014 exhibited no symptom and the virus was not detected in ELISA. As for MeCMV, the $\mathrm{F}_{1}$ was considered as susceptible because the virus was detected in all inoculated plants, indicating a recessive genetic control but the symptoms were only mild chlorotic spots.

In the $\mathrm{F}_{2}$ progeny, 25 plants among 200 inoculated plants exhibited no symptoms and were negative in ELISA, which did not correspond to a mono- or digenic inheritance (Supplementary Table S2). However, this observed segregation fit a 55 susceptible versus nine resistant expected segregation corresponding to one recessive and two dominant genes simultaneously required for resistance $\left(\chi^{2}=0.404 ; \mathrm{df}=1 ;\right.$ probability $\left.=52.5 \%\right)$. These genes can be provisionally symbolized $x, Y$, and $Z$.

Relationship between resistance to MeCMV and ToLCNDV. The $\mathrm{F}_{3}$ and $\mathrm{F}_{4}$ progenies derived from $\mathrm{F}_{2}$ plants resistant to MeCMV were inoculated with ToLCNDV (Table 3). Among $157 \mathrm{~F}_{3}$ and 250 $\mathrm{F}_{4}$ plants, 95 and 70 , respectively, were resistant to ToLCNDV. The $\mathrm{F}_{3} 1 \mathrm{~A} 8$ and the two corresponding $\mathrm{F}_{4} 1 \mathrm{~A} 8 \mathrm{~A}$ and $1 \mathrm{~A} 8 \mathrm{~B}$, which were homogeneously resistant to MeCMV, were also homogeneously resistant to ToLCNDV. This suggested a linkage or common genes for resistance to both viruses. A first hypothesis was a linkage between one of the genes for MeCMV resistance and one of the genes for ToLCNDV resistance with four subcases: (i) $a$ (or $b$ ) linked with $x$, (ii) $a$ (or $b$ ) linked with $Y$ (or $Z$ ), (iii) $C$ linked with $x$, and (iv) $C$ linked with $Y$ (or $Z$ ). A second hypothesis was two linkages with five

Table 2. Number of plants observed after inoculation with Melon chlorotic mottle virus (MeCMV) in the parents (Védrantais and IC-274014), $\mathrm{F}_{1}, \mathrm{~F}_{2}$, and backcross (BC) progenies

\begin{tabular}{|c|c|c|c|c|c|c|c|}
\hline & \multirow[b]{2}{*}{ Test } & \multirow[b]{2}{*}{ Total } & \multirow[b]{2}{*}{ Susc. ${ }^{a}$} & \multirow[b]{2}{*}{ Res. ${ }^{a}$} & \multirow[b]{2}{*}{ Segreg. ${ }^{b}$} & \multicolumn{2}{|r|}{$\chi^{2}$} \\
\hline & & & & & & Value & $\begin{array}{c}\text { Probability, } \\
\%\end{array}$ \\
\hline \multirow[t]{3}{*}{ Védrantais } & 1 & 30 & 30 & 0 & & & \\
\hline & 2 & 30 & 30 & 0 & & & \\
\hline & 3 & 10 & 10 & 0 & & & \\
\hline Total & & 70 & 70 & 0 & & & \\
\hline \multirow[t]{2}{*}{ IC-274014 } & 1 & 25 & 0 & 25 & & & \\
\hline & 2 & 25 & 0 & 25 & & & \\
\hline Total & & 50 & 0 & 50 & & & \\
\hline \multirow{2}{*}{$\begin{array}{l}\mathrm{F}_{1}=\mathrm{IC}- \\
274014 \times \\
\text { Védrantais }\end{array}$} & 1 & 25 & 25 & 0 & $1: 0$ & & \\
\hline & 2 & 22 & 22 & 0 & $1: 0$ & & \\
\hline Total & & 47 & 47 & 0 & $1: 0$ & & \\
\hline \multirow{3}{*}{$\mathrm{F}_{2}=\mathrm{F}_{1} \times \mathrm{F}_{1}$} & 1 & 99 & 97 & 2 & $61: 3$ & 1.577 & 21 \\
\hline & 2 & 80 & 78 & 2 & $61: 3$ & 0.857 & 35 \\
\hline & 3 & 250 & 234 & 16 & $61: 3$ & 1.641 & 2 \\
\hline Total & & 429 & 409 & 20 & $61: 3$ & 0.006 & 98 \\
\hline \multirow{2}{*}{$\begin{array}{c}\mathrm{BC}_{\mathrm{S}}=\mathrm{F}_{1} \times \\
\text { Védrantais }\end{array}$} & 1 & 50 & 50 & 0 & $1: 0$ & & \\
\hline & 2 & 47 & 47 & 0 & $1: 0$ & & \\
\hline Total & & 97 & 97 & 0 & $1: 0$ & & \\
\hline \multirow{2}{*}{$\begin{array}{r}\mathrm{BC}_{\mathrm{R}}=\mathrm{F}_{1} \times \\
\mathrm{IC}-274014\end{array}$} & 1 & 50 & 40 & 10 & $3: 1$ & 0.667 & 41 \\
\hline & 2 & 45 & 26 & 19 & $3: 1$ & 7.119 & 0.8 \\
\hline Total & & 95 & 66 & 29 & $3: 1$ & 1.547 & 21 \\
\hline
\end{tabular}

a Susceptible (Susc.) = with clear virus symptoms and/or positive detection by enzyme-linked immunosorbent assay (ELISA) or PCR; Resistant (Res.) = no symptom and no virus detection by ELISA or PCR.

${ }^{b}$ Expected segregation (Segreg.) (Susceptible:Resistant) under the hypothesis of two recessive and one dominant genes.

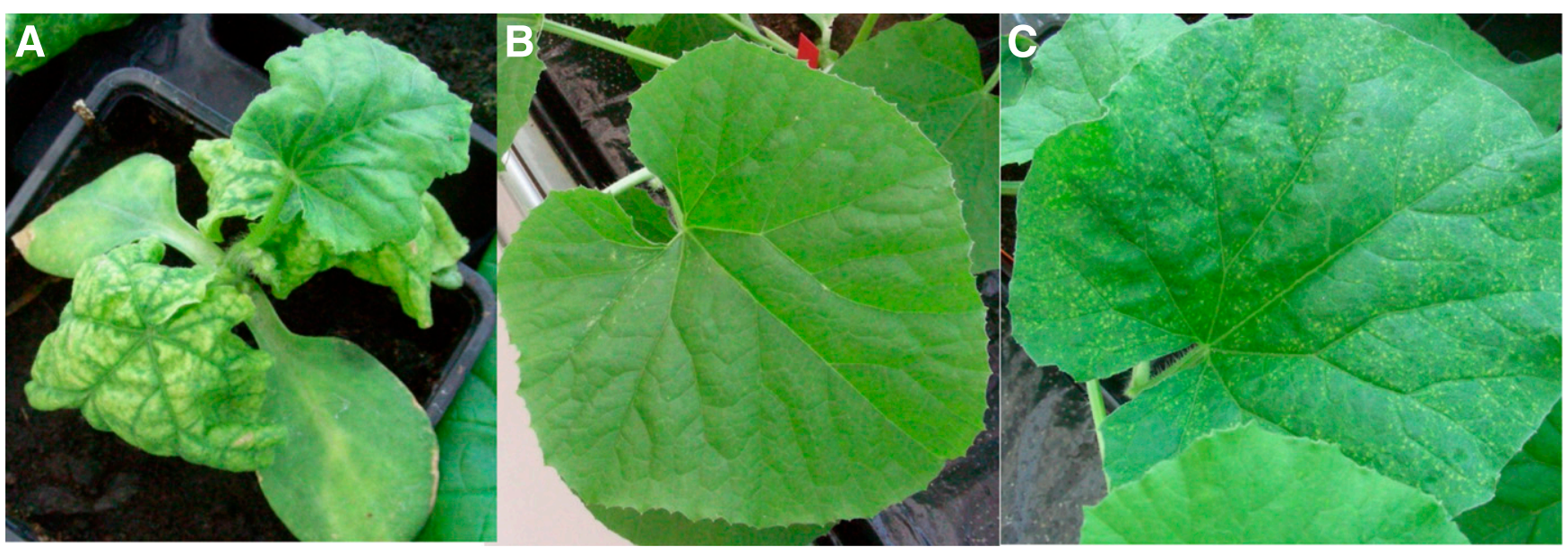

Fig. 1. Symptoms of Melon chlorotic mosaic virus (MeCMV): A, curling, yellowing, and stunting in the susceptible cultivar Védrantais; $\mathbf{B}$, no symptom and no virus multiplication in the resistant accession IC-274014; C, systemic chlorotic spots in the $\mathrm{F}_{1}$ (IC-274014 × Védrantais). 
subcases: (i) $a$ linked with $x$ and $b$ linked with $Y$ (or $Z$ ), (ii) $a$ linked with $Y$ and $b$ linked with $Z$, (iii) $a$ linked with $Y$ (or $Z$ ) and $C$ linked with $x$, (iv) $a$ linked with $Y$ and $C$ linked with $Z$, and (v) $a$ linked with $x$ and $C$ linked with $Y$ (or $Z$ ). The expected frequencies of resistant and susceptible plants to ToLCNDV were calculated under the conditions that $a$ and $b$ were homozygous and that $C$ was heterozygous $C C^{+}$or homozygous $C C$ for respectively two of three or one of three of the $\mathrm{F}_{3}$ progenies. Among these nine possibilities, two fit the observed segregation in the $\mathrm{F}_{3}$ progenies: linkages between $a$ and $x$ and between $b$ and $Y$ (probability $\chi^{2}=54.7 \%$ ) and linkages between $a$ and $x$ and between $C$ and $Y$ (probability $\chi^{2}=20.5 \%$ ) (Supplementary Table S3). For the $\mathrm{F}_{4}$ progenies, the probabilities of the $\chi^{2}$ were respectively $2.910^{-7}$ and $4.3 \%$ with in both cases an excess of observed susceptible plants. The best hypothesis is thus: $a$ linked with $x$, and $C$ linked with $Y$, whereas gene $b$ involved in MeCMV resistance and gene $Z$ involved in ToLCNDV resistance are independent. $\mathrm{F}_{3}$ plants homozygous resistant to both viruses, such as the $\mathrm{F}_{3} 1 \mathrm{~A} 8$, could be expected with a frequency of 1 of 12 ( 1 of 3 for $C-Y$ and 1 of 4 for $Z, a-x$, and $b$ being homozygous for resistance to MeCMV), which corresponds to the observed frequency of 1 homozygous resistant $F_{3}$ of 10 . The expected segregation for the number of susceptible:segregating:resistant $\mathrm{F}_{4}$ families toward ToLCNDV was 23:6:9. The observed values (respectively 8:13:2 in Table 3) fit this hypothesis $\left(\chi^{2}=5.778 ; \mathrm{df}=2\right.$; probability $\left.=5.6 \%\right)$.

Correlation with resistance to other viruses. IC-274014 was found resistant to ZYMV after mechanical inoculation (Supplementary Table S4). Among the $23 \mathrm{~F}_{4}$ (IC-274014 $\times$ Védrantais) progenies, 14 were symptomless, five displayed more or less severe symptoms of mosaics, yellowing and stunting, and four had a heterogeneous behavior (no symptoms, chlorotic spots, or mosaics). Among the 14 symptomless $\mathrm{F}_{4}$ progenies, five were positive in ELISA for at least one plant, being thus considered as heterogeneous $\left(\mathrm{F}_{4}\right.$ progenies $1 \mathrm{~A} 1 \mathrm{~A}, 1 \mathrm{~A} 3 \mathrm{~B}, 1 \mathrm{~A} 5 \mathrm{D}$, and $\left.1 \mathrm{~A} 7 \mathrm{~B}\right)$ or susceptible $\left(\mathrm{F}_{4}\right.$ progeny $1 \mathrm{~A} 1 \mathrm{~B})$.

In conditions of natural infection, IC-274014 was resistant to CABYV whereas Védrantais, the $F_{1}$ (IC-274014 $\times$ Védrantais) and the six tested $\mathrm{F}_{4}$ progenies were susceptible to the virus based on ELISA (Table 4). Among the tested accessions, HSD 2445-005, PI 414723, and WM9 were resistant to CABYV, whereas PI 164323, PI 164723, PI 179901, PI 234607, PI 236355, PI 482420, Védrantais, and WM7 were susceptible based on ELISA (Table 4). PI 414723 and Védrantais were confirmed as resistant and susceptible, respectively. All accessions were susceptible to CMV and WMV, whereas ZYMV was not present in the experimental plot (data not shown)

\section{Discussion}

Among the 31 melon accessions tested against MeCMV and ToLCNDV, most had similar behaviors toward both viruses. MeCMV and ToLCNDV are quite distant molecularly $(<60$ and $50 \%$ identity in DNA-A and DNA-B, respectively), and belong to different clades (NW vs. OW). However, MeCMV and ToLCNDV share a high infectivity when mechanically inoculated, a rare trait among begomoviruses even though it has been described in a few, particularly in the NW clade (Morales and Niessen 1988; Wege and Pohl 2007). This suggests that, like a few other begomoviruses, they are not exclusively phloem-limited, at least at some stages of their host development (Sudarshana et al. 1998). A common resistance mechanism may thus target the same key parameter in the cycle of these two viruses. Both viruses were also found associated with atypical alphasatellites in natural conditions (Anwar 2017; Romay et al. 2010). ToLCNDV also has been found associated with a betasatellite (Anwar 2017), contrary to MeCMV. The two viruses differ strikingly by their host range. MeCMV appears restricted to a few cucurbit hosts (Romay et al. 2015), whereas ToLCNDV has a broad host range including more than 40 species from a range of families including Cucurbitaceae, Solanaceae, Malvaceae, Amaranthaceae, Euphorbiaceae, and Fabaceae (Zaidi et al. 2017). In several accessions, intermediate resistance mechanisms appeared related to a "recovery" phenotype, as observed after melon or watermelon infection with CuLCrV (Hagen et al. 2008a). This suggests that the resistance could be related in these cases to RNA silencing (Ghoshal and Sanfaçon

Table 3. Number of plants susceptible or resistant to Melon chlorotic mottle virus (MeCMV) and Tomato leaf curl New Delhi virus (ToLCNDV) in the parents (Védrantais and IC-274014) and in the $\mathrm{F}_{3}$ and $\mathrm{F}_{4}$ progenies from $\mathrm{F}_{2}$ plants resistant to MeCMVa

\begin{tabular}{|c|c|c|c|c|c|c|c|c|c|}
\hline \multirow[b]{2}{*}{ Melon genotypes } & \multicolumn{2}{|c|}{ MeCMV } & \multicolumn{2}{|c|}{ ToLCNDV } & \multirow[b]{2}{*}{ Melon genotypes } & \multicolumn{2}{|c|}{ MeCMV } & \multicolumn{2}{|c|}{ ToLCNDV } \\
\hline & Susc. & $\overline{\text { Res. }}$ & Susc. & $\overline{\text { Res. }}$ & & Susc. & $\overline{\text { Res. }}$ & Susc. & $\overline{\text { Res. }}$ \\
\hline Védrantais & 16 & 0 & 16 & 0 & Védrantais & 20 & 0 & 10 & 0 \\
\hline IC-274014 & 0 & 15 & 0 & 20 & IC-274014 & 0 & 20 & 0 & 10 \\
\hline $\mathrm{F}_{3}$ progenies & & & & & $\mathrm{F}_{4}$ progenies & & & & \\
\hline \multirow[t]{2}{*}{$1 \mathrm{~A} 1$} & 3 & 7 & 4 & 6 & $1 \mathrm{~A} 1 \mathrm{~A}$ & 4 & 6 & 10 & 0 \\
\hline & & & & & $1 \mathrm{~A} 1 \mathrm{~B}$ & 14 & 5 & 14 & 6 \\
\hline \multirow[t]{2}{*}{$1 \mathrm{~A} 2$} & 4 & 14 & 13 & 5 & $1 \mathrm{~A} 2 \mathrm{~A}$ & 17 & 3 & 20 & 0 \\
\hline & & & & & $1 \mathrm{~A} 2 \mathrm{~B}$ & 1 & 9 & 9 & 1 \\
\hline \multirow[t]{2}{*}{$1 \mathrm{~A} 3$} & 5 & 15 & 7 & 13 & $1 \mathrm{~A} 3 \mathrm{~A}$ & 5 & 5 & 6 & 4 \\
\hline & & & & & $1 \mathrm{~A} 3 \mathrm{~B}$ & 0 & 25 & 3 & 7 \\
\hline \multirow[t]{2}{*}{$1 \mathrm{~A} 4$} & 14 & 3 & 6 & 11 & $1 \mathrm{~A} 4 \mathrm{~A}$ & 3 & 7 & 10 & 0 \\
\hline & & & & & $1 \mathrm{~A} 4 \mathrm{~B}$ & 7 & 3 & 8 & 2 \\
\hline \multirow[t]{4}{*}{$1 \mathrm{~A} 5$} & 5 & 4 & 5 & 4 & $1 \mathrm{~A} 5 \mathrm{~A}$ & 1 & 19 & 9 & 1 \\
\hline & & & & & $1 \mathrm{~A} 5 \mathrm{~B}$ & 0 & 20 & 10 & 0 \\
\hline & & & & & $1 \mathrm{~A} 5 \mathrm{C}$ & 1 & 19 & 10 & 0 \\
\hline & & & & & $1 \mathrm{~A} 5 \mathrm{D}$ & 0 & 20 & 10 & 0 \\
\hline \multirow[t]{3}{*}{$1 \mathrm{~A} 6$} & 0 & 6 & 3 & 4 & $1 \mathrm{~A} 6 \mathrm{~A}$ & 1 & 7 & 10 & 0 \\
\hline & & & & & $1 \mathrm{~A} 6 \mathrm{~B}$ & 1 & 4 & 9 & 1 \\
\hline & & & & & $1 \mathrm{~A} 6 \mathrm{C}$ & 16 & 4 & 10 & 0 \\
\hline \multirow[t]{2}{*}{$1 \mathrm{~A} 7$} & 6 & 14 & 6 & 14 & $1 \mathrm{~A} 7 \mathrm{~A}$ & 4 & 4 & 5 & 5 \\
\hline & & & & & $1 \mathrm{~A} 7 \mathrm{~B}$ & 1 & 19 & 3 & 7 \\
\hline \multirow[t]{2}{*}{$1 \mathrm{~A} 8$} & 0 & 17 & 0 & 18 & $1 \mathrm{~A} 8 \mathrm{~A}$ & 0 & 20 & 0 & 10 \\
\hline & & & & & $1 \mathrm{~A} 8 \mathrm{~B}$ & 0 & 20 & 0 & 10 \\
\hline \multirow{2}{*}{$1 \mathrm{~A} 10$} & 2 & 17 & 5 & 15 & $1 \mathrm{~A} 10 \mathrm{~A}$ & 3 & 7 & 2 & 8 \\
\hline & & & & & $1 \mathrm{~A} 10 \mathrm{~B}$ & 8 & 2 & 6 & 4 \\
\hline \multirow[t]{2}{*}{ 1A11 } & 4 & 13 & 13 & 5 & $1 \mathrm{~A} 11 \mathrm{~A}$ & 1 & 19 & 7 & 3 \\
\hline & & & & & $1 \mathrm{~A} 11 \mathrm{~B}$ & 3 & 13 & 9 & 1 \\
\hline
\end{tabular}

\footnotetext{
${ }^{\text {a }}$ Susceptible (Susc.) = with clear virus symptoms and/or positive detection by enzyme-linked immunosorbent assay (ELISA) or PCR; Resistant (Res.) = no symp-
} tom and no virus detection by ELISA or PCR. 
2015; Hagen et al. 2008a), although the actual mechanism remains unknown.

Accession IC-274014 was resistant (no symptoms and no virus detection by ELISA or PCR) to MeCMV. Different types of symptoms were observed in the $\mathrm{F}_{1}, \mathrm{~F}_{2}$, and $\mathrm{BC}$ progenies between IC274014 and the susceptible cultivar Védrantais: severe mosaic, mottle, systemic chlorotic spots. Inheritance of these different types of symptoms was difficult to analyze in terms of genetic control. The $\mathrm{F}_{1}$ exhibited systemic chlorotic spots, which were not observed in the parents. In the $\mathrm{F}_{2}$ or BC progenies, "recovery" phenotypes were often observed, with much higher symptom severity in the old leaves than in young ones. In plants with the different types of symptoms, the virus was always detected by ELISA or PCR. When using this criterion (presence vs. absence of virus), the observed segregations in the analyzed progenies fit the hypothesis of one dominant and two recessive independent genes simultaneously required for resistance.

Resistance of IC-274014 to ToLCNDV could be controlled by one recessive and two dominant genes. As some progenies selected at the $\mathrm{F}_{2}$ stage only for MeCMV resistance were also resistant to ToLCNDV, we concluded that common genes were involved in resistance to both viruses, even if the hypothesis of genes belonging to the same clusters cannot be completely ruled out, clusters of resistance genes being present in melon (Garcia-Mas et al. 2012; González et al. 2014). We propose the names begomovirus resistance-1 and Begomovirus resistance-2 for these genes (symbols $b g m-1$ and $B g m-2$ ), corresponding respectively to $a-x$ and $C-Y$ in the results section. For resistance to MeCMV, one more recessive gene was required corresponding to the locus $b$ in the results section; the name mecmv resistance (symbol mecmv) is proposed. Full resistance to MeCMV was controlled by bgm-1, Bgm-2, and mecmv. Resistance to ToLCNDV was controlled by $b g m-1, B g m-2$, and an additional dominant gene (proposed name ToLCNDV resistance, symbol Tolcndv) corresponding to the gene $Z$ in the results section.

Table 4. Behavior of melon accessions toward the four begomoviruses Melon chlorotic mosaic virus (MeCMV), Tomato leaf curl New Delhi virus (ToLCNDV), Cucurbit leaf crumple virus $(\mathrm{CuLCrV})$, and Watermelon chlorotic spot virus (WmCSV) and the polerovirus Cucurbit aphid-borne yellow virus $(\mathrm{CABYV})^{\mathrm{a}}$

\begin{tabular}{llllll}
\hline Accession & MeCMV $^{\mathbf{b}}$ & ToLCNDV $^{\mathbf{b}}$ & CuLCrV $^{\mathbf{c}}$ & WmCSV $^{\mathbf{d}}$ & CABYV $^{\mathbf{b}, \mathbf{e}}$ \\
\hline Védrantais & $\mathrm{S}$ & $\mathrm{S}$ & $\mathrm{nt}$ & $\mathrm{S}$ & $\mathrm{S}$ \\
HSD & Segreg & Segreg & $\mathrm{nt}$ & $\mathrm{R}$ & $\mathrm{R}$ \\
2445-005 & (R/S) & (R/S) & & & \\
IC-274014 & $\mathrm{R}$ & $\mathrm{R}$ & $\mathrm{nt}$ & $\mathrm{nt}$ & $\mathrm{R}$ \\
Kharbuja & $\mathrm{nt}$ & $\mathrm{IR}^{\mathrm{f}}$ & $\mathrm{nt}$ & $\mathrm{nt}$ & $\mathrm{nt}$ \\
PI 124111 & $\mathrm{IR}$ & $\mathrm{IR}^{\mathrm{R}}$ & $\mathrm{R}$ & $\mathrm{nt}$ & $\mathrm{nt}$ \\
(MR-1) & & & & & \\
PI 124112 & $\mathrm{R}$ & $\mathrm{IR}^{\mathrm{f}} / \mathrm{R}$ & $\mathrm{IR}$ & $\mathrm{R}$ & $\mathrm{R}^{\mathrm{g}}$ \\
PI 164323 & $\mathrm{S}$ & $\mathrm{S}$ & $\mathrm{nt}$ & $\mathrm{nt}$ & $\mathrm{S}$ \\
PI 164723 & $\mathrm{S}$ & $\mathrm{IR}$ & $\mathrm{R} / \mathrm{IR}$ & $\mathrm{R}$ & $\mathrm{S}$ \\
PI 179901 & $\mathrm{IR}$ & $\mathrm{R}$ & $\mathrm{IR}$ & $\mathrm{nt}$ & $\mathrm{S}$ \\
PI 234607 & $\mathrm{S}$ & $\mathrm{S}$ & $\mathrm{R}$ & $\mathrm{nt}$ & $\mathrm{S}$ \\
PI 236355 & $\mathrm{S}$ & $\mathrm{S}$ & $\mathrm{R}$ & $\mathrm{nt}$ & $\mathrm{S}$ \\
PI 282448 & $\mathrm{R}$ & $\mathrm{R}$ & $\mathrm{nt}$ & $\mathrm{R}$ & $\mathrm{R}$ \\
PI 313970 & $\mathrm{R}$ & $\mathrm{IR}$ & $\mathrm{R}$ & $\mathrm{R}$ & $\mathrm{R}^{\mathrm{g}}$ \\
(90625) & & & & & \\
PI 414723 & $\mathrm{IR}$ & $\mathrm{IR}$ & $\mathrm{IR}$ & $\mathrm{R}$ & $\mathrm{R}$ \\
WM7 & $\mathrm{R}$ & $\mathrm{R}^{\mathrm{f}} / \mathrm{R}$ & $\mathrm{nt}$ & $\mathrm{nt}$ & $\mathrm{S}^{\mathrm{h}}$ \\
WM9 & $\mathrm{R}$ & $\mathrm{IR} / \mathrm{R}$ & $\mathrm{nt}$ & $\mathrm{nt}$ & $\mathrm{R}$ \\
\hline
\end{tabular}

${ }^{\text {a }} \mathrm{S}=$ susceptibility, $\mathrm{R}=$ resistance, $\mathrm{IR}=$ partial resistance, $\mathrm{nt}=$ not tested.

$\mathrm{b}$ This work, unless otherwise specified.

${ }^{\mathrm{c}}$ McCreight et al. 2008.

d Yousif et al. 2007.

${ }^{\mathrm{e}}$ Results from field trial based on enzyme-linked immunosorbent assay (ELISA) test.

f López et al. 2015.

g Dogimont et al. 1996.

${ }^{\mathrm{h}}$ Low ELISA values.
The susceptible $\mathrm{F}_{4}$ plants after inoculation with MeCMV or ToLCNDV exhibited mild symptoms (mottling or systemic chlorotic lesions) and not the severe symptoms (mosaic and stunting) observed in the susceptible control Védrantais. Consequently, bgm-1 and/or $B g m-2$ could be involved in the control of the severe symptoms.

Accession IC-274014 is also resistant to ZYMV and CABYV, but no correlation was observed between resistance to ZYMV or CABYV on the one hand, and to MeCMV or ToLCNDV on the other hand.

Genes conferring resistance to several viruses from the same family, or even to completely different pathogens, have already been described. This can be dominant genes (e.g., the $L$ gene conferring resistance to seven tobamoviruses in pepper, see Moury and Verdin 2012) or recessive ones. Recessive resistance is often related to the loss or modification of a susceptibility factor required for the viral cycle, notably eukaryotic initiation factor 4E (Kuwata 2016; Robaglia and Caranta 2006). A recessive resistance gene to the begomovirus tomato yellow leaf curl virus, $t y-5$, corresponds to the tomato homo$\log$ of the messenger RNA surveillance factor Pelota (Lapidot et al. 2015) and conferred resistance in field conditions to at least five tomato-infecting begomovirus species (Al-Shihi et al. 2018). The resistance abolished symptoms and reduced viral accumulation (Anbinder et al. 2009). Besides ty-5, additional minor quantitative trait loci contributed to the resistance (Anbinder et al. 2009). A similar situation may happen for MeCMV and ToLCNDV resistance in melon, although the nature of bgm- 1 and the mechanisms of resistance remain unknown so far.

A pool of melon accessions with resistance to one or several begomoviruses is emerging from the literature (Table 4). Most of them are from India and belong to the acidulus, momordica, or kachri groups (Pitrat 2016b). The most recent publication on genetic control was on the resistance to ToLCNDV of the accession WM7 from India belonging to the kachri group: a major dominant gene (on linkage group LG XI) and two minor quantitative trait loci (QTLs) (on LG II and LG XII) (Sáez et al. 2017). From our results, resistance in IC274014 is also controlled by three genes, one recessive (bgm-1) and two dominant (Bgm-2 and Tolcndv), suggesting that common genes could be involved in WM7 and IC-274014. It would be interesting to search for the candidate regions for the different resistance genes.

Several accessions belonging to different horticultural types (e.g., cantaloupes, honeydew, cassaba) were resistant to CuLCrV (Hagen et al. 2008b) after agroinoculation. Resistance in the accession PI 313970 after inoculation by $B$. tabaci was controlled by one recessive gene, culcrv (McCreight et al. 2008). Allelism tests indicate that the same gene was also probably present in other resistant accessions, such as MR-1, PI 124111, PI 124112, PI 179901, PI 234607, and PI 236355 (McCreight et al. 2008); PI 236355, which exhibited the best level of resistance to $\mathrm{CuLCrV}$, was susceptible to MeCMV and ToLCNDV (Table 4). So the gene culcrv is probably not involved in resistance to these two last viruses, and different from bgm-1or mecmv.

Resistance to WmCSV after Agrobacterium-mediated inoculation was observed in several accessions (Yousif et al. 2007). Accessions resistant to WmCSV were also partially or completely resistant to MeCMV and ToLCNDV (Table 4). The inheritance of resistance to $\mathrm{WmCSV}$ has not been published. It would be interesting to test IC-274014 and the $\mathrm{F}_{4}$ (IC-274014 $\times$ Védrantais) resistant or susceptible to MeCMV and ToLCNDV for their behavior when inoculated with WmCSV.

Our results suggest that although some resistance factors to begomoviruses are specific, common broad-spectrum resistance genes may be present in melon germplasm and could constitute interesting tools for breeders.

\section{Acknowledgments}

We thank the Experimental Infrastructure team of INRA-Montfavet for their help in the greenhouse experiments. We thank D. Besombes for obtaining part of the melon accessions and crosses and Dr J.E. Duffus (USDA, Salinas) for providing the SLCV antiserum. 


\section{Literature Cited}

Al-Shihi, A. A., Hanson, P., Al-Sadi, A. M., Al-Yahyai, R. A., Briddon, R. W., Deadman, M., and Shahid, M. S. 2018. Evaluation of tomato inbred lines for resistance to the tomato yellow leaf curl disease complex in Oman. Crop Prot. 110:91-98.

Anbinder, I., Reuveni, M., Azari, R., Paran, I., Nahon, S., Shlomo, H., Chen, L., Lapidot, M., and Levin, I. 2009. Molecular dissection of Tomato leaf curl virus resistance in tomato line TY172 derived from Solanum peruvianum. Theor. Appl. Genet. 119:519-530.

Anwar, S. 2017. Distinct association of an alphasatellite and a betasatellite with Tomato leaf curl New Delhi virus in field-infected cucurbit. J. Gen. Plant Pathol. 83:185-188.

Brown, J. K., Zerbini, M., Navas-Castillo, J., Moriones, E., Ramos-Sobrinho, R., Silva, J. C. F., Fiallo-Olive, E., Briddon, R. W., Hernandez-Zepeda, C., Idris, A., Malathi, V. G., Martin, D. P., Rivera-Bustamante, R., Ueda, S., and Varsani, A. 2015. Revision of Begomovirus taxonomy based on pairwise sequence comparisons. Arch. Virol. 160:1593-1619.

Cohen, S., Duffus, J. E., Larsen, R. C., Liu, H. Y., and Flock, R. A. 1983. Purification, serology, and vector relationships of squash leaf curl virus, a whitefly-transmitted geminivirus. Phytopathology 73:1669-1673.

Dhillon, N. P. S., Ranjana, R., Singh, K., Eduardo, I., Monforte, A. J., Pitrat, M., Dhillon, N. K., and Singh, P. P. 2007. Diversity among landraces of Indian snapmelon (Cucumis melo var. momordica). Genet. Resour. Crop Evol. 54: 1267-1283.

Dogimont, C., Slama, S., Martin, J., and Pitrat, M. 1996. Sources of resistance to cucurbit aphid-borne yellows luteovirus in a melon germ plasm collection. Plant Dis. 80:1379-1382.

Fortes, I. M., Sánchez-Campos, S., Fiallo-Olivé, E., Díaz-Pendón, J. A., NavasCastillo, J., and Moriones, E. 2016. A novel strain of tomato leaf curl New Delhi virus has spread to the Mediterranean Basin. Viruses 8:307.

Garcia-Mas, J., Benjak, A., Sanseverino, W., Bourgeois, M., Mir, G., González, V. M., Hénaff, E., Câmara, F., Cozzuto, L., Lowy, E., Alioto, T., CapellaGutiérrez, S., Blanca, J., Cañizares, J., Ziarsolo, P., Gonzalez-Ibeas, D., Rodríguez-Moreno, L., Droege, M., Du, L., Alvarez-Tejado, M., LorenteGaldos, B., Melé, M., Yang, L., Weng, Y., Navarro, A., Marques-Bonet, T., Aranda, M. A., Nuez, F., Picó, B., Gabaldón, T., Roma, G., Guigó, R., Casacuberta, J. M., Arús, P., and Puigdomènech, P. 2012. The genome of melon (Cucumis melo L.). Proc. Natl. Acad. Sci. USA 109:11872-11877.

Ghoshal, B., and Sanfaçon, H. 2015. Symptom recovery in virus-infected plants: Revisiting the role of RNA silencing mechanisms. Virology 479-480:167-179.

Gilbertson, R. L., Rojas, M. R., Russell, D. R., and Maxwell, D. P. 1991. Use of the asymmetric polymerase chain reaction and DNA sequencing to determine genetic variability of bean golden mosaic geminivirus in the Dominican Republic. J. Gen. Virol. 72:2843-2848.

González, V., Aventin, N., Centeno, E., and Puigdomenech, P. 2014. Interspecific and intraspecific gene variability in a $1-\mathrm{Mb}$ region containing the highest density of NBS-LRR genes found in the melon genome. BMC Genomics 15:1131.

Hagen, C., Rojas, M. R., Kon, T., and Gilbertson, R. L. 2008a. Recovery from Cucurbit leaf crumple virus (family Geminiviridae, genus Begomovirus) infection is an adaptive antiviral response associated with changes in viral small RNAs. Phytopathology 98:1029-1037.

Hagen, C., Rojas, M. R., Sudarshana, M. R., Xoconostle-Cazares, B., Natwick, E. T., Turini, T. A., and Gilbertson, R. L. 2008b. Biology and molecular characterization of Cucurbit leaf crumple virus, an emergent cucurbitinfecting Begomovirus in the Imperial Valley of California. Plant Dis. 92: 781-793.

Juárez, M., Tovar, R., Fiallo-Olivé, E., Aranda, M. A., Gosalvez, B., Castillo, P., Moriones, E., and Navas-Castillo, J. 2014. First detection of tomato leaf curl New Delhi virus infecting zucchini in Spain. Plant Dis. 98:857.

Kuwata, S. 2016. Plant viral translation strategies and disease resistance conferred by recessive host genes. J. Gen. Plant Pathol. 82:318-322.

Lapidot, M., Gelbart, D., Gal-On, A., Sela, N., Anfoka, G., Haj Ahmed, F., AbouJawada, Y., Sobh, H., Mazyad, H., Aboul-Ata, A. A., Kamal El-Attar, A., AliShtayeh, M. S., Jamous, R. M., Polston, J. E., and Duffy, S. 2014. Frequent migration of introduced cucurbit-infecting begomoviruses among Middle Eastern countries. Virol. J. 11:181.
Lapidot, M., Karniel, U., Gelbart, D., Fogel, D., Evenor, D., Kutsher, Y., Makhbash, Z., Nahon, S., Shlomo, H., Chen, L., Reuveni, M., and Levin, I. 2015. A novel route controlling Begomovirus resistance by the messenger RNA surveillance factor Pelota. PLoS Genet. 11:1005538.

Lecoq, H., Wilser, G., and Pitrat, M. 1998. Cucurbit viruses: the classics and the emerging. Pages126-142 in: Proceedings of Cucurbitaceae 98. ASHS \& U.S. Dep. Agric.-ARS, Pacific Grove, CA.

Lecoq, H., and Pitrat, M. 1984. Strains of zucchini yellow mosaic virus in muskmelon (Cucumis melo L.). J. Phytopathol. 111:165-173.

López, C., Ferriol, M., and Pico, M. B. 2015. Mechanical transmission of Tomato leaf curl New Delhi virus to cucurbit germplasm: selection of tolerance sources in Cucumis melo. Euphytica 204:679-691.

Mallor, C., Alvarez, J. M., and Luis-Arteaga, M. 2003. A resistance to systemic symptom expression of melon necrotic spot virus in melon. J. Am. Soc. Hortic. Sci. 128:541-547.

McCreight, J. D., Liu, H.-Y., and Turini, T. A. 2008. Genetic resistance to Cucurbit Leaf Crumple Virus in melon. HortScience 43:122-126.

Morales, F. J., and Niessen, A. I. 1988. Comparative responses of selected Phaseolus vulgaris germ plasm inoculated artificially and naturally with bean golden mosaic virus. Plant Dis. 72:1020-1023.

Moriones, E., Praveen, S., and Chakraborty, S. 2017. Tomato leaf curl New Delhi virus: an emerging virus complex threatening vegetable and fiber crops. Viruses 9:264.

Moury, B., and Verdin, E. 2012. Viruses of pepper crops in the Mediterranean Basin: a remarkable stasis. Adv. Virus Res. 84:127-162.

Pitrat, M. 2016a. Disease resistance in melon and its modification by molecular breeding techniques. Pages 175-197 in: Functional Genomics and Biotechnology in Solanaceae and Cucurbitaceae Crops, edited by Ezura, H., Ariizumi, T., Garcia-Mas, J., and Rose, J.. Springer, Berlin.

Pitrat, M. 2016b. Melon genetic resources: phenotypic diversity and horticultural taxonomy. Pages 25-60 in: Genetics and Genomics of Cucurbitaceae, edited by Grumet, R., Katzir, N., and Garcia-Mas, J. Springer, Cham, Switzerland.

Robaglia, C., and Caranta, C. 2006. Translation initiation factors: a weak link in plant RNA virus infection. Trends Plant Sci. 11:40-45.

Romay, G., Chirinos, D., Geraud-Pouey, F., and Desbiez, C. 2010. Association of an atypical alphasatellite with a bipartite New World Begomovirus. Arch. Virol. 155:1843-1847.

Romay, G., Lecoq, H., and Desbiez, C. 2015. Melon chlorotic mosaic virus and associated alphasatellite from Venezuela: genetic variation and sap transmission of a Begomovirus-satellite complex. Plant Pathol. 64:1224-1234.

Romay, G., Lecoq, H., Geraud-Pouey, F., Chirinos, D. T., and Desbiez, C. 2014 Current status of cucurbit viruses in Venezuela and characterization of Venezuelan isolates of Zucchini yellow mosaic virus. Plant Pathol. 63:78-87.

Ruiz, M. L., Simon, A., Velasco, L., Garcia, M. C., and Janssen, D. 2015. First report of tomato leaf curl New Delhi virus infecting tomato in Spain. Plant Dis. 99:894.

Sáez, C., Esteras, C., Martinez, C., Ferriol, M., Dhillon, N. P. S., Lopez, C., and Pico, B. 2017. Resistance to tomato leaf curl New Delhi virus in melon is controlled by a major QTL located in chromosome 11. Plant Cell Rep. 36: 1571-1584.

Sudarshana, M. R., Wang, H. L., Lucas, W. J., and Gilbertson, R. L. 1998. Dynamics of bean dwarf mosaic geminivirus cell-to-cell and long-distance movement in Phaseolus vulgaris revealed, using the green fluorescent protein. Mol. Plant-Microbe Interact. 11:277-291.

Wege, C., and Pohl, D. 2007. Abutilon mosaic virus DNA B component supports mechanical virus transmission, but does not counteract begomoviral phloem limitation in transgenic plants. Virology 365:173-186.

Wyatt, S. D., and Brown, J. K. 1996. Detection of Subgroup III geminivirus isolates in leaf extracts by degenerate primers and polymerase chain reaction. Phytopathology 86:1288-1293.

Yousif, M. T., Kheyr-Pour, A., Gronenborn, B., Pitrat, M., and Dogimont, C. 2007. Sources of resistance to watermelon chlorotic stunt virus in melon. Plant Breed. 126:422-427.

Zaidi, S., Martin, D. P., Amin, I., Farooq, M., and Mansoor, S. 2017. Tomato leaf curl New Delhi virus: a widespread bipartite Begomovirus in the territory of monopartite begomoviruses. Mol. Plant Pathol. 18:901-911. 